Peter Bogh Andersen

\title{
Arbejde og tegn
}

Nogle resultater fra et forskningsprojekt om edbsystemer, arbejde og sprog

\section{Projektet »Fagsprog i forandring"}

I denne artikel vil jeg fremlægge nogle resultater fra projektet $\gg$ Fagsprog i forandring «. Projektet er et dansk-svensk projekt der er finansieret delvist af det svenske akademi, delvist af det danske humanistiske forskningsråd. Det blev udført i perioden efteråret 86 til foråret 88 af Berit Holmqvist og undertegnede, på Institut for Informations- og Medievidenskab, Århus Universitet. Vi undersøgte en afdeling på Postgiro i Stockholm, mens man erstattede de gamle mekaniske kodemaskiner med edb-systemer, samtidig mod at man ændrede arbejdsorganiseringen, således at den enkelte fik større ansvar.

Projektets formål var:

"l. at beskrive hvordan organisatoriske forandringer på en arbejdsplads påvirker de ansattes sprogbrug og kommunikationsmønster, med særligt hensyn til sådanne forandringer, som sker ved datorisering,

2. at udforske hvilke praktiske retningslinjer man ud fra sprogbrugsanalysen kan opstille for design af edb-systemer.«

Denne artikel handler kun om punkt 2. Mere fyldige beskrivelser af hele projektet kan findes andre steder. ${ }^{1}$

Når projektets formål overhovedet kunne lade sig opfylde beror det på, at arbejdssproget på den pågældende afdeling blev beskrevet $\mathrm{i}$ 1982-83. Vi havde således den unikke situation at vi kendte den sproglige før-situation på arbejdspladsen. ${ }^{2}$

\section{Materiale}

For at opfylde formålet indsamlede vi i efteråret 1986 et korpus bestående af følgende:

Arbejdskommunikation: 6 transskriptioner af spontant arbejdssprog på 5-10 sider hver, samt 2 transskriptioner af fremkaldt højttalen under arbejdet, 3-4 sider hver. 
Interviews: 2 interviews med systemkoordinator og vejleder. Papirbaseret: De relevante manualer og kravsspecifikationen. Sk\&rmbilleder: 50 billeder fra den ene højttalersession og en systematisk udskrift af hele systemet.

Desuden opholdt Berit Holmqvist sig jævnligt på arbejdspladsen og tog notater.

\section{Metoder}

På dette materiale har vi anvendt en række traditionelle lingvistiske metoder og begreber.

Til at beskrive de leksikalske forandringer, der sker som følge af de teknologiske og organisatoriske ændringer, viste ideen om semantiske felter sig meget anvendelig. Man udvælger et sæt af sammenlignelige genstande eller arbejdsoperationer fra før- og eftersituationen, og beskriver forskelle og ligheder i den måde, hvorpå arbejdssproget lægger grænserne ned i disse. De semantiske felter viste sig også gode til at beskrive perspektivforskelle i de forskellige gruppers arbejdssprog.

Til at beskrive sproget i brug har vi anvendt sprogspilsbegrebet. Ved et sprogspil forstår jeg den mindste sproglige enhed, som har funktion til ikke-sproglige fænomener som f.eks. arbejdsopgaverne. I sin indre opbygning kan et sprogspil karakteriseres som en sekvens af træk (f.eks. situationsfastlæggelse - regelsøgning i problemløsningsspil) som indgår gensidige funktioner og er forenet under samme kommunikative formål (som f.eks. i arbejdsfordeling der knytter en bestemt arbejder til en bestemt arbejdsopgave). Endelig kan et sprogspil karakteriseres ved hvilke paradigmer der er lukkede og hvilke der er åbne (f.eks. er paradigmet af arbejdsopgaver lukket i arbejdsfordeling, mens paradigmet af arbejdere er åbent: vi har valgt arbejdsopgaven, den er ikke til diskussion, mens det står åbent hvem der skal udføre den).

Syntaktisk analyse har bl.a. været brugt til at karakterisere perspektivforskelle mellem forskellige gruppers sprog, og mellem edb-systemets "sprog « og brugernes.

Materialet viste ganske tydeligt, at indførelse af edb-systemer er en slags sprogkamp (mere eller mindre fordragelig) mellem forskellige grupper i organisationen der har hvert sit fagsprog og hvert sit syn på organisationen og arbejdet. Det skyldes dels at systemet konstrueres af én gruppe (systemafdelingen), der sætter sit præg på det, men skal bruges af andre grupper, dels at mange forskellige grupper skal bruge det samme system, og derfor stiller forskellige krav til det. 
Endelig sigtede projektet også mod at tilpasse den generelle tegnteo$r i$, således at den dels kan anvendes til at beskrive de specielle tegn, man træffer i et edb-systems grænseflade, dels kan fungere som hjælpevidenskab for design af edb-systemer. Det kræver nogle ændringer i teorien fordi edb-baserede tegn indeholder håndteringsegenskaber som en vigtig del af deres virkemidler. F.eks. kan man ikke kun passivt aflæse skærmens elementer men også påvirke dem på forskellig måde.

\section{Design af edb-systemer med udgangspunkt $i$ arbejde og kommunikation}

Begrebsdannelse og sprog ændrer sig, når edb-systemer vinder indpas på en arbejdsplads eller et fag, og derfor er det nyttigt at vide, hvad der sker og hvordan det sker, både for at kunne vurdere den sprogpolitiske side af teknologiudviklingen, men også for at kunne konstruere systemer, der fungerer godt $\mathrm{i}$ deres brugssammenhæng.

Hvad vil det så sige, at et tegnsystem som et edb-system passer ind i den kommunikation og det arbejde, hvor det skal bruges?

En forudsætning for at kunne diskutere sammenhængen mellem så forskellige størrelser som edb-systemer, menneskelig kommunikation og menneskeligt arbejde, er at alle tre beskrives ud fra samme generelle begrebsramme og finder en velbegrundet plads her. Traditionelt gør man det at man udvider begreber, som er udviklet til at beskrive edb-systemer, til også at beskrive kommunikation og arbejde, idet man ser kommunikation og arbejde gennem systemkonstruktørens briller. Til bestemte formål indenfor systemudviklingsprocessen er det godt og nyttigt, men absolut ikke tilstrækkeligt, fordi kommunikation og arbejde ikke er det samme som udførelse af algoritmiske processer. Derfor er det nødvendigt at anvende flere optikker, og i det følgende søger jeg at udvide lingvistikkens begrebsapparat, som er godt til at beskrive sprog og kommunikation, til også at dække edbsystem og arbejdsprocesser. Jeg vælger så at sige at se system og arbejde gennem lingvistens briller, velvidende at der stadig er ting jeg ikke kan se.

\section{Opbygning af edb-baserede tegn ${ }^{3}$}

Jeg starter med at skitsere hvordan edb-systemet kan beskrives. Systemet skal da betragtes som et tegnsystem, og det har umiddelbart den konsekvens, at jeg gennem lingvistikkens optik kun kan se de sider af systemet som vender ud mod brugeren og som faktisk fungerer som tegn.

Jeg kan naturligvis ikke her give en udtømmende redegørelse, men 
vælger at illustrere med begreberne styring og kongruens der kendes helt tilbage fra antikkens sprogfilosofi. ${ }^{4}$

At et led A styrer et andet led B vil sige, at egenskaber hos A fremkalder bestemte egenskaber hos B, som B ikke ville have hvis $\mathrm{A}$ ikke var tilstede. Ydermere skal de to sæt egenskaber være forskellige. Præpositioner styrer f.eks. akkusativ (Han kommer hen til mig, ikke Han kommer hen til jeg), og de finitte tider i verbet styrer nominativ (Han kommer, ikke Ham kommer).

Ved kongruens foregår stort set det samme, kun er egenskaberne hos A og B de samme. Tal og køn kongruerer i et udtryk som Den kloge hund, idet både den og klog skal være samme køn (sammenlign Et klogt barn), og alle tre led skal være samme tal (sammenlign De kloge born).

Kongruens og styring er sammen med ledstillingsregler med til at angive, hvilke ord der hører sammen og danner mere komplekse betydninger, og edb-mediet viser sig at bruge de samme virkemidler. Det er nemmest at illustrere med grafiske systemer, og derfor vender jeg kort blikket mod den Macintosh jeg bruger til at skrive denne artikel.

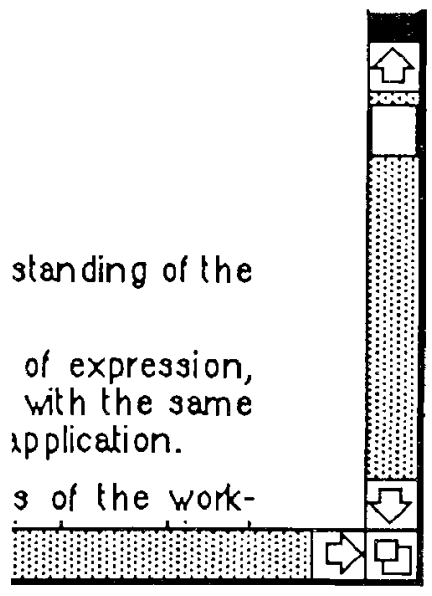

Fig.I

På vedstående billede har jeg vist en såkaldt scroll-bar, som man bruger til at bladre i sit dokument. Når man bevæger firkanten nedad, skal teksten bevæge sig opad, og teksten og scroll-baren danner sammen et sammensat tegn der kan parafraseres: Jeg bladrer $i$ teksten med scroll-baren. I det daglige arbejde med systemet er det vigtigt, at sådanne sammensatte betydninger fremstår tydeligt og klart, og man benytter sig i mange tilfælde af styring og kongruens. I eksemplet er der styring mellem tekstens og scroll-barens bevægelser: går scroll-baren op, går teksten ned, og omvendt.

På systemer med mus afspejles musens bevægelser altid af en săkaldt hård cursor på skærmen. Bevæges musen til venstre, går cursoren også den vej. Her er tale om kongruens mellem musens og cursorens bevægelser.

$\mathrm{Vi}$ er ofte ikke kun interesserede $\mathrm{i}$ at fremstille sammenhænge for brugeren - de skal også kunne tolkes som udtrykkende bestemte 
betydninger. F.eks. giver det et godt orienteringsgrundlag ${ }^{5}$, hvis nogle edb-baserede tegn kan opfattes som værktøjer, mens andre ses som arbejdsgenstande, der kan påvirkes af værktøjet, men hvordan skal systemet opbygges, så brugeren faktisk foretager den ønskede fortolkning?

Et muligt svar kan være, at tegnet for værktøjet skal indeholde en kongruens mellem brugerens fysiske bevægelser og egenskaber ved værktøjsikonet, og at disse egenskaber skal styre eller kongruere med egenskaber ved arbejdsgenstandsikonet.

Med en solid teoretisk ramme, der omfatter både arbejdssprog og edb-system, vil man være bedre rustet til at skabe systemer, der fungerer godt i det sproglige og begrebsmæssige miljø, de skal anvendes i. Mange problemer med edb-systemer skyldes, at de begreber, systemet er bygget op omkring og den måde de præsenteres på, er fremmede for sproget hos den profession, der skal bruge systemet, og udtrykker et utilstrækkeligt kendskab til fagområdet.

Et arbejdssprog bør studeres seriøst af systemudviklere, fordi dets begreber er velbegrundede i sprogbrugernes praktiske erfaringer. En god måde at starte systemudviklingen på er faktisk at lave en undersøgelse af det eksisterende arbejdssprog ${ }^{6}$ : hvad er vigtige begreber? Hvordan hænger de sammen? Hvornår bruges de? Analyse af arbejdssprog og arbejdsprocesser er efter min mening kun mulig sammen med de mennesker der bruger sproget og udfører arbejdet. De design-aktiviteter, der omtales i det følgende, forudsætter derfor deltagelse af såvel edb-specialister som brugere, og udtrykkene vi og man dækker disse to grupper.

\section{Analyse af sprog, arbejde og organisation}

Det er imidlertid ikke nok at bringe arbejdssprog og edb-system på samme teoretiske fod. Vi må også kunne forstå sprog og system i deres samspil med arbejdsopgave og organisation.

De tegn, som forekommer på edb-systemers skærme, har nemlig en langt tættere tilknytning til disse ikke-sproglige foreteelser end andre tegn. Ved hjælp af tegn skal konstruktøren af systemet fortælle mig, hvad jeg nu kan/skal gøre (prompts, feed-back), om jeg har gjort noget »forkert« eller »farligt " (fejlmeddelelser, advarsler), og de ord, han præsenterer mig for, skal jeg kunne bruge til at diskutere konkrete problemer med kolleger, og jeg skulle også gerne kunne anvende dem til at skabe mig en generel begrebsramme, så jeg kan forstå, hvad det er jeg gør (brugsmodel). Alle disse meddelelser skal gives $i$ et sprog, der kan forbindes meningsfuldt med det sprog jeg iøvrigt bruger til at forstå og diskutere mit arbejde i. 
Ikke blot er der en tæt tilknytning til arbejdsprocessen, men også til den måde, den kan organiseres på: systemer kan være konstrueret sådan, at de indbyder til skarp eller løs arbejdsdeling, til enkeltpersonsarbejde eller kollektivt arbejde, til byrokratisk organisering, hvor man skal have tilladelser til alt man gør, eller til en mere uformel måde at arbejde på.

Når vi beskriver grænsefladen til et edb-system, er vi derfor interesserede $i$ at kunne få denne beskrivelse til at hænge sammen med en beskrivelse af den arbejdsproces og organisation, hvori systemet skal bruges. Og har jeg startet med at bruge sprogvidenskabelige begreber til at forstå grænsefladen med, må jeg forsøge at udstrække dem, så de også kan bruges til at forstå arbejdsproces og organisation med.

Her kunne de tre grammatiske forholdsarter sideordning, underordning og nexus komme på tale. ${ }^{7}$ To led er sideordnede năr det ene led ikke er en forudsætning for forekomsten af det andet. Semantisk spiller de hver for sig samme rolle $\mathrm{i}$ forhold til et tredje led. I sætningen

Ved at bruge samme begrebsapparat til såvel grænseflade som arbejde og organisation, vil vi kunne oparbejde en sammenhængende forståelse af deres samspil.

er arbejde og organisation sideordnede, og kaldes et paratagme.

To led er underordnede, når forekomsten af det ene er en forudsætning for forekomsten af det andet, men ikke omvendt, og kun det første har et forhold til et tredje led. I en sammenhangende forståelse er sammenhengende underordnet forstålse. De to led kaldes et hypotagme.

Endelig danner to led nexus, hvis de gensidigt forudsætter hinanden, og kun sammen har forhold til et tredje led. Vil vi danner en nexus.

I det efterfølgende symboliserer jeg hypotakse ved en pil fra det underordnede til det overordnede led, og nexus symboliseres ved en dobbelthovedet pil. Man kan, som naturligt er, bruge disse begreber til at beskrive opbygningen af et edb-baseret tegn, men man kan også forsøge at udstrække dem til at beskrive samspillet mellem system og arbejdsproces.

Et af de væsentligste problemer i design af edb-systemer er at få systemet til at hænge sammen med arbejdsprocessen på en god måde. Men

Hvornår er det god sammenheng mellem tegnsystem og arbejdsproces?

Jeg vil prøve at besvare spørgsmålet gennem fem tilnærmelser. Men først vil jeg sige lidt om hvordan edb-baserede tegn helt generelt 
hænger sammen med arbejde. Der er to hovedmåder, der begge er hypotagmer:

1. tegnet kan være en forudsætning for en handling eller en ytring i arbejdet. Et bestemt billede i Postgiro-systemet er f.eks. en forudsætning for at arbejderen kan rette fejl, og rapporteringsskærmbilleder, der viser hvor mange kort der indtil nu er behandlet, giver ofte grundlag for diskussioner om arbejdsgangen. Her er handlingen eller ytringen underordnede og afhængige af tegnet, for fejlretningen og diskussionen forekommer kun hvis tegnene forekommer, mens tegnene godt kan forekomme uden fejlretning eller diskussion.

2. en handling kan være en forudsætning for, at tegnet fremkommer eller forsvinder. F.eks. kan indtastning af et tal frembringe en ny menu på skærmen, og på Postgiro er det fysiske arbejde ved OCRlæseren en forudsætning for at de elektroniske kort senere kommer op på arbejds-stationernes skærme. Tegnet er her styret af og underordnet handlingen.

I det følgende vil jeg se på fire funktioner som edb-baserede tegn skal udfylde $\mathbf{i}$ arbejdsprocessen, nemlig

- som forudsætning for rutinehandling

- som forudsætning for problemløsningssamtale

- som forudsætning for "teorikonstruktion"

- som forudsætning for arbejdsfordeling og koordinering.

Tegnsystemet som forudsætning for rutinehandling

Jeg tænker her på rutineanvendelsen, hvor man udfører sit arbejde ved skærmen uden særlige problemer. Det første bud på "god sammenhæng « forekommer mig her at være en eller anden lighed mellem tegnsystem og arbejde.

Ideen er at tage udgangspunkt $\mathrm{i}$ arbejdsprocessen, inddele den $\mathrm{i}$ momenter, der har navne i arbejdssproget, registrere de syntaktiske forhold mellem arbejdsmomenterne, skabe de edb-baserede tegn som udgør forudsætning for de enkelte arbejdsmomenter, samt skabe de samme syntaktiske relationer mellem tegnene som hersker mellem de arbejdsmomenter de hænger sammen med.

(1) De syntaktiske relationer mellem skærmtegnene skal være de samme som dem der hersker mellem de handlinger, tegnene hænger sammen med.

For at dette kan lade sig gøre, må der foreligge konkrete arbejdsprocesser. Er man i gang med at ændre arbejdet samtidig med, at man laver systemet, kan man ikke bruge de eksisterende processer direkte, 
skønt meget naturligvis kan læres af dem. Man må derfor simulere de nye arbejdsprocesser, enten ved hjælp af "pap og papir« eller ved hjælp af prototypeværktøjer. Det er en vigtig pointe, at der må foreligge faktiske, konkrete processer og ikke kun beskrivelser heraf, for at metoden kan anvendes. Lingvistikkens metoder er ikke gearet til at beskrive beskrivelser af sprog, men til at belyse sprogbrugen selv.

Princip (1) kan forekomme næsten trivielt. Hvis jeg sommetider udfører en handling $\mathrm{Hl}$, der forudsætter tegnet $\mathrm{Tl}$, sammen med en anden handling $\mathrm{H} 2$, der forudsætter tegnet $\mathrm{T} 2$, og sommetider kun handling $\mathrm{H} 1$, men aldrig $\mathrm{H} 2$ uden $\mathrm{H} 1$, så er $\mathrm{H} 2$ underordnet $\mathrm{Hl}$, og da de to tegn er forudsætninger for overhovedet at udføre handlingerne, så må T2 også være underordnet T1. Sommetider optræder T1 alene på skærmen, somme tider sammen med T2, men T2 vil aldrig optræde alene.

Det trivielle er dog kun tilsyneladende. T1 og T2 vil nemlig typisk være sammensatte tegn, og deres bestandele kan godt vise sig at indgå helt andre relationer indbyrdes, end T1 og T2 selv. Lad mig illustrere med scroll-bar eksemplet.

Antag vi vil lave et tekstbehandlingsprogram, og begynder med at studere skriveprocessen. Vi opdager at handlingerne lose og bladre praktisk taget altid begge udføres i samme session, dvs. de indgår en nexus. Lase forudsætter kun teksten, mens bladre forudsætter en styring mellem scroll-bar og tekst. Det betyder at teksten altid skal forekomme, mens scroll-bar + tekst sommetider skal forekomme. Altså: selvom handlingerne lase og bladre danner nexus, danner deres tegndele scroll-bar og tekst et hypotagme. På grundlag af denne viden kunne man igen beslutte sig til, at scroll-baren skal designes som et pop-up tegn der kun bliver synligt når man fører curseren ud til siden af papiret. ${ }^{8}$

I det følgende anlægger jeg sådanne betragtningsmåder på de arbejdsprocesser, som foregår ved Postgiros nye edb-system, og jeg forestiller mig, at formålet med øvelsen er at ændre systemet, så det passer bedre med dette arbejde. Mit eksempel er en meget forenklet udgave af fejlhåndtering som den foregik på Postgiro. Arbejderen sidder og inddaterer de håndskrevne tal på indbetalingskortet og jeg ser på to fejlsituationer:

1. der mangler et kort i bundtet, dvs. der er »underskud« i bundtet, og

2. der er et kort for meget i bundtet og dermed »overskud«. 


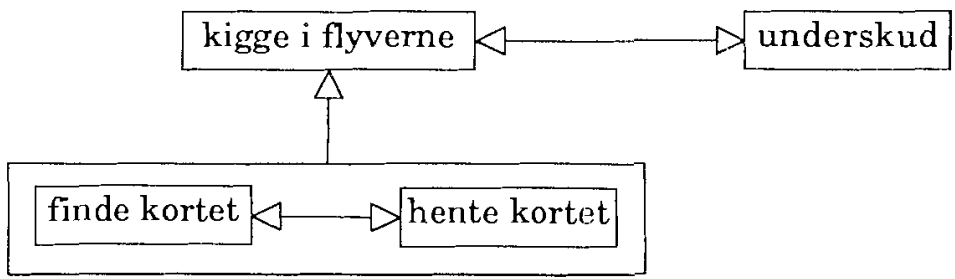

Fig.2

I første fejlsituation skal man kigge i »flyverne« (en file hvor arbejderne kan lægge overflødige kort) om kortet er blevet placeret der af en kollega, så handlingsmæssigt er der nexus mellem »underskud « og »kigge i flyverne«. Hvis man finder kortet i flyverne, er der en arbejdsorganisatorisk regel, der siger, at så skal man hente det og placere det i sit eget bundt, og da vil »hente« danne nexus med "finde kortet« og begge vil være underordnet »kigge i flyverne«.

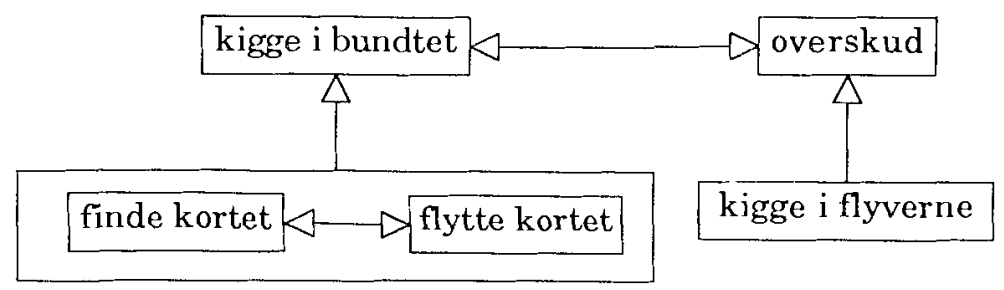

Fig.3

I anden fejlsituation vil man kigge $\mathrm{i}$ bundtet af indbetalingskort for at finde det ekstra kort, man skal flytte til »flyverne», mens man normalt ikke kigger i flyverne - skønt der kan muligvis være tilfælde hvor man har brug for det. Der kan derfor ikke være nexus men højst hypotakse mellem »overskud« og »kigge i flyverne«. Lad os herudover sige at et kort i overskud altid skal flyttes til flyverne, dvs. at der hersker nexus mellem »overskud« og »flytte«. 


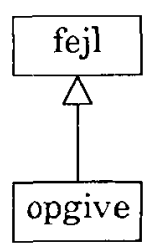

Fig.4
Lad os tilslut give den regel, at hvis man ikke kan finde ud af det, må man »opgive«, dvs. lægge det problematiske bundt til side, se på det senere eller fả andre til at kigge på det. Handlingen »opgive" er ikke specielt knyttet til nogen speciel af de to fejlsituationer, men snarere til hele kategorien af fejlsituationer. Da man godt kan have en fejlsituation uden at opgive, men ikke opgive uden at have en fejlsituation, må »opgive« være underordnet kategorien af fejlsituationer.

Alle disse observationer vedrører de arbejdsmæssige syntagmer, dvs. hvilke arbejdsmomenter der forekommer sammen (både-og). Diagrammerne ovenfor er syntagmer, der beskriver arbejdsmomenternes forløb i tid, og ideen i at lave dem er at gøre det tydeligt, at f.eks. det tegn, som bruges når vi kigger i flyverne, skal være obligatorisk $\mathrm{i}$ underskuds-, men ikke overskudssituationen, at tegnene for at flytte og hente kort altid skal forekomme sammen med tegn for at finde og udvælge kort, og at der skal være en »opgive« kommando i begge fejlsituationer, således at brugeren ikke tvinges til at vente i 10 minutter ved skærmen, fordi den kollega, der kan hjælpe, er gået til frokost.

Men vi kan også gøre observationer vedrørende paradigmer bag arbejdsmønstrene, dvs. hvilke arbejdsmomenter der kan forekomme på samme plads i processen men udelukker hinanden (enten-eller). F.eks. er det klart, at »opgive « på den ene side og »hente« og »flytte« på den anden side gensidigt udelukker hinanden, og det samme gælder »underskud « og »overskud «. Paradigmer symboliserer jeg ved at placere leddene under hinanden i en kasse.

Det var arbejdsprocessen. Lad os så se på de edb-baserede tegn, jeg skal bruge:

FEJL:

underskud på $465 \mathrm{kr}$
Tegnet for fejl kan bestå af overskriften FEJL, og de to fejltyper markeres ved et valg fra paradigmet [underskud, overskud].

Fig.5 


\section{Opgiv}

Fig.6

BUNDT:

$x x x x x x$

$x \times x \times x x$

$x \times x \times x x$

Fig.7

FLYVERE:

$X X X X X X$

$x x x x x x$

$x x x x x x$

Fig.8

\begin{tabular}{|c|}
\hline Op \\
\hline Ned \\
\hline Vælg Kont \\
\hline
\end{tabular}

Fig.9

Hent kort

Fig.10

Flyt kort

Fig.11
Tegnet for at opgive er en kommando »Opgiv«. Kommandoen er underordnet kategorien af fejlsituationer, fordi den altid kan, men ikke skal anvendes.

Bundtet fremvises altid i fejlsituationen, og indgår derfor nexus med denne. Set ud fra arbejdsanalysen er bundtet kun nødvendigt når et overskydende kort skal udpeges og flyttes, men jeg tror at de problemlosningssamtaler, der udspiller sig i fejlsituationer, meget ofte vil forudsætte at bundt-tegnet forekommer på skærmen.

Flyverne fremvises kun i underskudssituationen, når bundtet mangler et kort, der måske kan hentes fra flyverne. I overskudssituationen kan en kommando evt. fremkalde flyver-billedet.

Disse tre kommandoer udtrykker processen »lede efter og evt. finde et kort«. De danner et paradigme, der er underordnet en kategori som vi kan kalde »lister af kort« hvortil flyver- eller bundtbilledet hører. De to forste kommandoer får en cursor til at bevæge sig op og ned i listen, og den sidste bruges til at markere valget af et kort.

Tegnet for at hente et kort fra flyverne.

Tegnet for at flytte et kort til flyverne. 
At opbygge interaktion vil sige at danne syntagmer af ovennævnte tegn. I det følgende viser jeg en mulighed, der i høj grad tager udgangspunkt i arbejdsprocesanalysen:

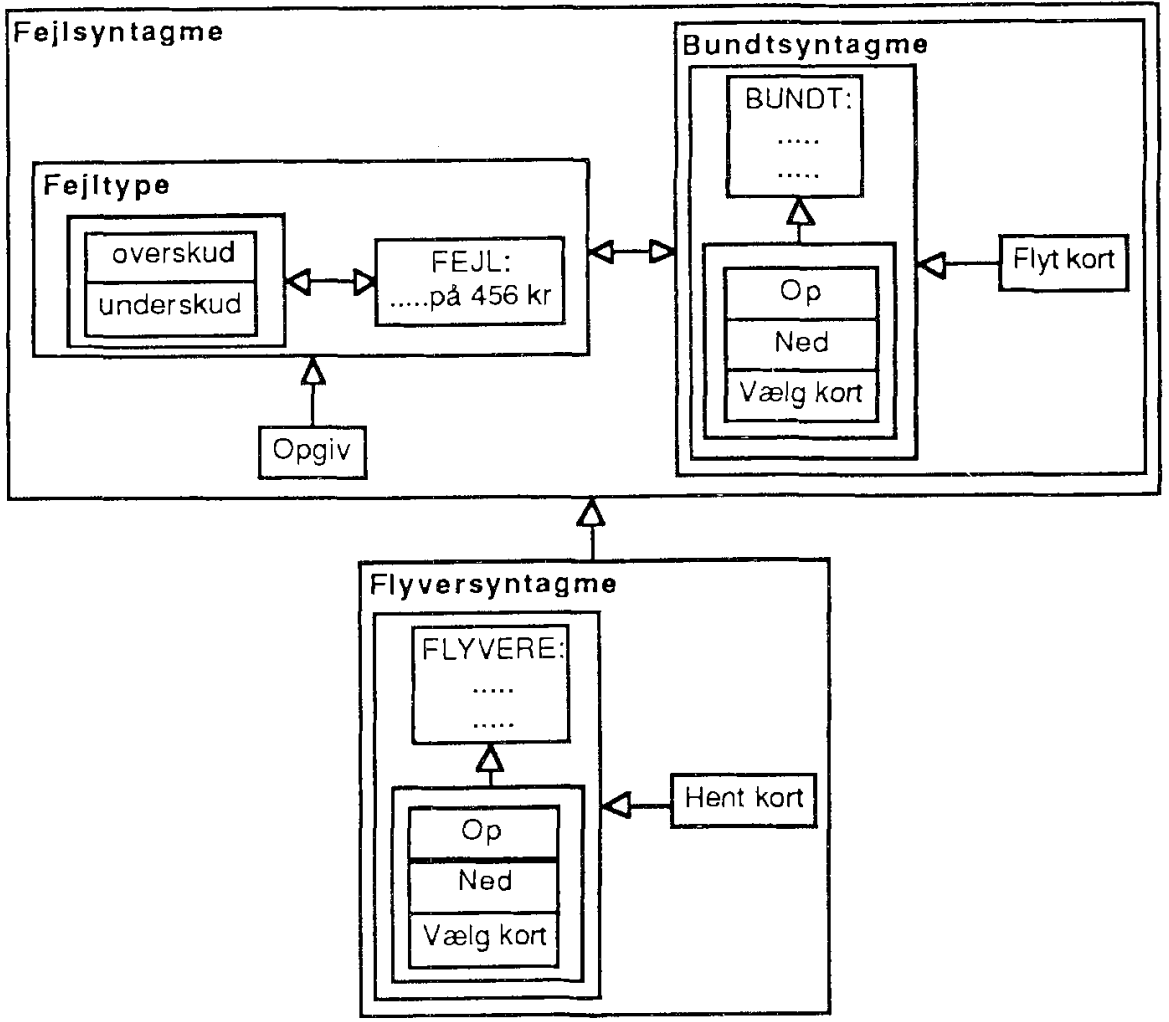

Fig.12

Der er et hovedsyntagme bestående af to led, Fejlsyntagmet og Flyversyntagmet, hvoraf det sidste er underordet det første. Dette afspejler forholdene $\mathrm{i}$ arbejdsprocessen, hvor man kun var nødt til at kigge $\mathrm{i}$ flyverne i underskudssituationen. Fejlsyntagmet består af en nexus mellem et Fejltypesyntagme og Bundtsyntagmet. Her afviger jeg fra arbejdsprocessen, hvor man kun i overskudssituationen skulle kigge $\mathrm{i}$ bundtet for at finde det kort der skulle flyttes.

Grunden til at jeg altid vil have bundtsyntagmet på skærmen i fejlsituationen er, at det kan være bekvemt at fă overblik over hele ens arbejdsgenstand i en sådan situation. Og det virkelige Postgirosystem er da også konstrueret på den måde. Bundt- og Flyversyntagmet ligner hinanden, idet de består af en liste af kort med tilhørende kommandoer, hvortil er knyttet enten Flyt eller Hent kort. 
Man vil lægge mærke til, at traditionelle datalogiske begreber som dekomponering og klassifikation ${ }^{9}$ også optræder her, idet syntagmer dekomponeres i deres led og kan tilhøre mere generelle kategorier af syntagmer (klassifikation). Det specielle ved begreberne her er 1. at de konsekvent tolkes som udsagn om tegn, og 2. at de eksplicit er udledt af arbejdsprocessen.

Tegnsystemet som forudsætning for problemløsning

Materialet fra Postgiro viser imidlertid, at de edb-baserede tegn ikke kun indgår forudsætningsrelationer med rutinehandlinger, men også med forskellige typer af sprogspil. Problemløsning er et sådant spil. Det spilles tit i fejlsituationer, og består i Postgiros regelbaserede arbejde af to hoveddele: en fastlæggelse af fejlsituationen, efterfulgt af søgning efter den korrekte regel at bruge. Her er et par eksempler:

\section{Fejlsituation}

E: vet du vad han har gjort, han har gjort så här ${ }^{10}$

$\mathrm{X}$ : å han har slagit det där, å nu ser jag det, inte tittar jag så där noggrannt

Regelsagning

$\mathrm{E}$ : det där får du macka bort eller lämna in i buren

$\mathrm{X}$ : ja just det

E: han har ju, han har ju

X: ja, vänta nu får vi se, då får jag ta, då mackar jag bort hela bunten

Fejlsituation

M: nä nu har jag nåt ännu konstigare (....)

M: titta här, 80, det misstämmer 492 och 70 (..)

$\mathrm{X}$ : ja just det, det har jag macka bort

M: varför det nu da

$\mathrm{X}$ : det är jag som har macka bort det, för det va ett sånt där konstigt kort /skratt/ (...)

$\mathrm{X}$ : jo därför att, därför att det va ingen sån där grön greja, så den där /skratt/(...)hmhm/skratt -skratt/

M: där ser man (...)/skratt/

Regelsogning

M: den ska vi nästan skicka till flygare, det har du inte gjort? $\mathrm{X}$ : nej (....) jag har tagit bort det

Der er to ting vi skal lægge mærke til: for det første optræder de handlingsmæssige paradigmer som syntagmer i sproget. Macka bort (=Ta bort) og Lämna in er handlingsmæssige paradigmer, de kan 
forekomme på samme plads i arbejdsprocessen, de udelukker gensidigt hinanden, og en af dem skal vælges. Men i sætningen står der faktisk macka bort eller lämna in i buren. Enten-eller rela tionen verbaliseres som en både-og relation. For det andet omtales der handlinger som ikke foretages ved hjælp af edb-systemet, idet lämna in $i$ buren betyder, at bundtet fysisk overlades til en specialafdeling, der kan finde ud af hvad der skal gøres. Problemløsningsspil som de citerede kan naturligvis understøttes af manualer, men jeg kan ikke se nogen grund til, at det ikke kan gøres af systemet, så derfor foreslår jeg følgende udvidelse af (1):

(2) I tilgift til (1) skal der være mulighed for at fremkalde billeder, hvor de syntaktiske relationer mellem skærmtegnene er de samme som dem, der hersker mellem ytringerne i de problemløsningssprogspil, de hænger sammen med.

Det kunne praktisk betyde, at billeder byggende på fig. 12 blev vist $i$ forste omgang: disse billeder viser den helt essentielle information, og vil kunne bruges i mange tilfælde. Når der opstår tvivl, og man făr fat i en kollega for at diskutere sagen, skal der kunne fremkaldes et nyt billede, som evt. blot kan være en udvidelse af det forste, hvor de handlingsmæssige paradigmer optræder som tekstuelle syntagmer, f.eks. i form af traditionelle menuer, og derfor kan understøtte samtalen. Mange systemer, som f.eks. Macintosh, tilbyder allerede disse to valgmuligheder: man kan enten fremkalde en menu, der fremviser de mulige operationer, hvoraf en så vælges, eller man kan direkte indtaste en kort kommando uden at se menuen. Min pointe her er, at disse to interaktionsformer skal være knyttet til bestemte momenter i arbejdsprocessen: kommandointeraktion til rutinemomenter, menuen til problemløsningssituationer.

Dette problemløsningsbillede kunne udmærket være struktureret som typiske problemløsningsspil, hvor angivelse af fejlsituationen var knyttet til mulige regler. Når fejlsituationen skal håndteres ved hjælp af systemet (f.eks. skicka till flygare) er reglen identisk med en kommando der kan bruges, og når det ikke er tilfældet (lämna in i buren) får man en kort beskrivelse af, hvad man selv skal gøre.

Der er imidlertid fejl som systemet ikke reagerer på. Det er nemlig egenskaber ved papirkortet, som ikke er repræsenteret i maskinen, og et eksempel herpå er underskriften. Hver betalingsordre skal være underskrevet, og kort uden underskrift skal man Ta bort hvorefter de kan blive sendt tilbage til kunden. Hverken princip (1) eller (2) tager højde for den situation, og det vil være ret katastrofalt, hvis man glemte det i praksis. Da ville arbejderen stå i den situation, at hun vidste at kortet var fejlagtigt, men eftersom systemet ikke detekterer 
fejlen, vil det ikke gå i fejlmodus, og derfor ikke fremvise de nødvendige kommandoer. Det giver os følgende tilføjelse:

(3) I tilgift til (2) skal arbejderen selv altid have mulighed for at fremkalde den tegnkonfiguration som hun mener beskriver arbejdssituationen korrekt.

Tegnsystemet som forudsætning for »teorikonstruktion« Arbejde er imidlertid ikke kun rutinehandlinger og problemløsninger. Arbejde består også i at forstå, at danne sig et helhedsbillede, der ligesom sprogsystemet kommer til at ligge som en forudsatning for de efterfølgende konkrete handlinger man foretager. I vores data er der mange eksempler på en slags »teorikonstruktion«, hvor arbejderne sammen forsøger at forklare tilsyneladende uforklarlig adfærd fra systemet, eller prøver at diskutere sig frem til, hvilke muligheder systemet giver dem i deres arbejde. I det efterfølgende eksempel opdager $\mathrm{L}$ at "flyverne" fra foregående dag stadig ligger i flyverfilen, selv om de alle er blevet hämtat og placeret i de korrekte bundter. Tre, fire personer forsøger at opklare mysteriet, og udkaster hypoteser som at de bliver liggende et vist antal dage, og de kommer tilbage nar man starter op på ny.

\section{Mysterium}

L: hörrudu Anki? Vad är det här?

A: det är inte dom i alla fall, det vet ja, för dom va 80,82 , $81,82,83$

L: två nämen, va är det hära, det är ju flygarna, jag fick se nu, att det va en flygare

A: men det va ju tomt igår, nä det här måste va en checkflygare (..)

L: nä det här va konstigt, det här begriper inte jag, titta här när jag sitter och tittar här, "antal flygare 8 « (....)

\section{Hypotese}

$\mathrm{X}$ : de kanske är ett visst antal dagar man kan gå tillbaks å se dom

Y: ja ja, det tror jag med, dom ligger kvar

L: det här e ju dagens datum eller hur, det är ju 0370

Y: för hon va ju å lyssna på den där, Sylvia, och de va ju okej va (.....)

\section{Hypotese}

Y: det kanske kommer tillbaka, när man startar upp på nytt, med nya uppgifter

G: ja nu ska vi tänka här 
L.: dom där från sjätte va försvunna igår här (....)

Y: man måste ju få kolla när man avslutar, att man har det rent här

$\mathrm{X}: \mathrm{ja}$

Y: i och med att man startar upp på nytt, då kommer dom där tillbaka $(\ldots .$.

Hypotese

$\mathrm{X}$ : dom är det

L: ja här, det va dom där ja vi tog bort (....)

$\mathrm{X}$ : ungefar $i$ tre dagar verkar dom ligga kuar

A: å det här e ju

G: det är ju samma dag alltihopa

A: gamla flygare, borttagna flygare

Y: dom försvinner nog antagligen sen

L: ja det tror jag med dom där andra försvann

$\mathrm{X}$ : det făr vi se, när det kommer in nya da

Y: dom e faktiskt borta på måndag

Skønt mange af den slags samtaler har karakter af gætteri fordi de nødvendige informationer mangler, bruges der megen tid på dem. De er vigtige for arbejderne, der ikke kun ønsker at følge givne regler, men også at forstå dem, og jeg synes at et godt design også bør understøtte sådanne samtaler. Man skal som konstruktør ikke blot tænke på brugerne som målrettede personer med rent instrumentel interesse i systemet, men også som nysgerrige, fortolkende individer, der ønsker at skabe sammenhæng i det de gør. I det aktuelle tilfælde ville diskussionen have været hjulpet godt på vej af en log-funktion, der opsamlede væsentlige hændelser (som f.eks. at flytte og hente flyvere) og præsenterede dem overskueligt. Ved at afspille loggen fra de nærmeste dage, ville samtaledeltagerne have mulighed for at opdage mønstre $\mathrm{i}$ den måde flyverne kom og forsvandt på.

(4) I tilgift til (3) skal tegnsystemet have et historisk afsnit, hvor fortidige hændelser præsenteres på en overskuelig måde, som kan understøtte brugernes teori-konstruktion.

Tegnsystemet som forudsætning for arbejdsfordeling og koordinering Mange systemer tapper data om de ansattes arbejdspræstationer og laver statistikker på dem til brug for ledelsen. Den slags nøglehulskiggeri har der været berettiget modstand imod, men jeg vil prøve at vende sagen lidt på hovedet her.

I Postgirosystemet er der et rapporteringsmodul, der opsamler 
tidstro oplysninger om, hvordan arbejdet skrider frem: hvor mange kort der er behandlet, hvor mange jobs der er færdige, hvor mange lådor der er sendt til datahallen, etc. På vores bånd kunne vi iagttage, at de ansatte selv var begyndt at bruge rapporteringsmodulet, der vistnok blot var beregnet på at give ledelsen rapporter om driften, til at folge med i hvor langt kollegerne var kommet, og selv omfordele arbejdet, hvis der var flaskehalse. I følgende citat diskuterer to arbejdere hvor mange jobs deres kolleger $i$ en anden sektion har tilbage, og hvor mange lador de har sendt:

X: ja det där ser ju bra ut åtminstone, men vi ska väl titta, om vi har nånting mer nu da

M: har du titta på den

$X:$ nä jag titta inte på den, jag titta på

X: titta, här är dom där två jobben kvar på 142:an, kom du ihåg det, dom där två igår som vi fick ta bort

M: va då

$\mathrm{X}$ : dom här två jobben här ser du, det vart ju två jobb-

$\mathrm{M}:(\ldots)$

$\mathrm{X}$ : ja precis

$\mathrm{X}$ : dom har nånting kvar

M: dom har ett jobb kvar

$\mathrm{X}$ : titta nu här har dom

M: har dom bara

$\mathrm{X}$ : dom har bara två jobb

M: dom har kanske kört en låda, men det tror jag inte dom kan, fôr det är så lite dom har kört på den där maskinen (....)

M: men dom har sänt en, och sen har dom en kvar

$\mathrm{X}: \mathrm{ja}$

Lidt provokativt kunne man sætte følgende regel op:

(5) I tilgift til (2) skal der være mulighed for at fremkalde billeder, der opsamler tidstro data om arbejdets fremadskriden, og som kan bruges som støtte for arbejdernes planlægning, fordeling og koordinering af arbejdet.

\section{Stilarter}

Iagttagelser og anbefalinger som disse kan give anledning til at opstille mere generelle forskrifter for designstil.

Det skandinaviske Utopia-projekt" har opstillet følgende kriterier for god edb-støtte til håndværkspræget arbejde: 
Værktøjer skal være

- midler til at omforme råmateriale til et mere forfinet produkt

- under komplet og kontinuerlig manuel kontrol af arbejderen

- udformet til at blive brugt af en fagkyndig arbejder til at skabe produkter af god brugsværdi

- videreudviklinger af den akkumulerede viden om værktøjer og materialer i en given arbejdsproces.

Og det må være muligt at udforme lignende kriterier for god edbstøtte til industriarbejde. Den afgørende forskel vil komme til at ligge i kravet om »komplet og kontinuerlig manuel kontrol«. Her er et forslag som man kan kalde for industristilen i modsætning til Utopias håndvarkstil:

Tydelig overensstemmelse mellem dele af tegnsystemet og den regelstyrede arbejdsproces det bruges i, hvor udgangspunktet for overensstemmelsen skal ligge $\mathrm{i}$ arbejdsprocessen(l).

Tegnsystcmet skal understøtte problemløsende og teoriskabende samtaler. Som eksempel på det første kan anføres, at hvis arbejdet er regelbaseret, bør systemet kunne fremvise de mulige regler for brugeren. Som eksempler på det andet kan nævnes, at tegnsystemet bør kunne præsentere fortidige hændelser på en overskuelig måde. Da industriarbejde ofte er udformet som et hierarki, hvor den enkelte proces er inddelt i mindre processer, og hvor nogle processer udfores i helt andre afdelinger, således at man ofte ikke ved hvad der sker med ens eget produkt når det går videre, ber tegnsystemet fremvise hierarkiet tydeligt for brugerne, således at man făr en god forståelse af hvilken funktion ens eget arbejde har i forhold til andres(2,4).

Arbejderen bør altid selv have mulighed for at fremkalde den tegnkonfiguration som hun mener beskriver arbejdssituationen korrekt(3).

Tegnsystemet skal understøtte arbejderne i at planlægge, fordele og koordinere arbejdet. Systemet skal give brugerne gode muligheder for at få informationer om, hvordan arbejdet skrider frem, for at sende meddelelser der tjener til at koordinere det, og give faciliteter for at planlægge $\operatorname{det}(5)$.

Mens værktøjs-systemets emne er værktøjer og arbejdsgenstande, skal industri-systemet handle om et kompliceret net af arbejdsopga- 
ver, der planlægges og udføres af mange mennesker, hvis aktiviteter griber ind $i$ hinanden og derfor skal koordineres. Man kan sige at industrisystemets emne bør være planlægning, koordination og kommunikation.

\section{Noter}

1. En beskrivelse af den nuvarende tilstand og de forandringer, der er foregået, findes i $\mathbf{B}$. Holmqvist: Datorisering av sprảk och arbete og Work and Perspective. Institut for Informations og Medievidenskab, Ârhus Universitet: 1988, samt i en større bog jeg har på trapperne $A$ semiotic approach to computer science.

2. Vedrorende den tidligere sprogtilstand, se B.Holmqvist og G.Källgren: Postgirot som spräkmiljö I-II. Institutionen för Nordiska Språk, Stockbolms Unjversitet: 1986.

3. Se iøvrigt min og Jorgen Lindskov Knudsens: Semantics for interactive graphical systems. Institut for Informations og Medievidenskab/Datalogisk Afdeling, Århus Universitet: 1988.

4. Mere moderne behandlinger findes i L. Hjelmslev: La notion de reaction (Essais Linquistiques, Les Editions de minuit: 1971), og P.Diderichsen: Morpheme categories in modern Danish (L. Hjelmslev (red.): Recherces structurales, Nordisk Sprog-og Kulturforlag: 1949).

5. Pelle Ehn \& Morten Kyng: A tool perspective on design of interactive computer systems for skilled workers. I M.Sääksjärvi (red.): Proceedings from the Seventh Scandinavian Research Seminar on Systemeering. Helsinki: 1984

6. Om metoder hertil, se min og Kim Halskov Madsens »Metaforer i design og brug af edbsystemer«. Symposiet "Computers, cognition \& epistemology", Psykologisk Institut, 2426/4, 1987. Kommer i »Computers, Mind and Metaphor«: Erlbaum.

7. Paul Diderichsen: Elementar Dansk Grammatik. Gyldendal: 1962. Se også L. Hjelmslev: Omkring Sprogteoriens Grundlaggelse. Kobenhavn: 1943.

8. Nogle Xerox-systemer virker sådan.

9. N.E.Andersen m.fl. Professionel systemudiikling, kap.9.3. Teknisk Forlag, 1986.

10. Kunden har fort et af beløbene i betalingsordren ned som sum.

11. Se f.eks. Pelle Ehn: Work-Oriented Design of Computer Artifacts. Arbetslivscentrum: 1988. 